\title{
Responsiveness in vitro of porcine luteal tissue recovered at two stages of the luteal phase
}

\author{
Morag G. Hunter* \\ Centre for Reproductive Biology, University of Edinburgh, Department of Obstetrics and \\ Gynaecology, 37 Chalmers Street, Edinburgh EH3 9EW, U.K.
}

\begin{abstract}
Summary. Corpora lutea (CL) were recovered from pigs at $6 \frac{1}{2}$ or $12 \frac{1}{2}$ days after induced ovulation and fragments of tissue and isolated cells were incubated for $3 \mathrm{~h}$ in vitro. Progesterone synthesis by tissue and cells from $12 \frac{1}{2}$ day CL was stimulated by bovine LH $(1 \mu \mathrm{g} / \mathrm{ml})$, dibutyryl cyclic AMP (10 mM) and hCG $(10-50 \mathrm{i} . \mathrm{u} . / \mathrm{ml})$ but $6 \frac{1}{2}$ day $\mathrm{CL}$, although having a higher level of control synthesis, did not respond to these substances. The addition of testosterone $(100 \mathrm{ng} / \mathrm{ml})$ to the incubations was found to suppress the response to bovine $\mathrm{LH}$ in the $12 \frac{1}{2}$ day tissue and cells. Separation of the dissociated luteal cells into populations of large and small sized cells demonstrated that the large cells were more synthetically active than the small cells, but cells of both sizes in the $12 \frac{1}{2}$ day CL responded to bovine $\mathrm{LH}$. These results support the concept that the porcine CL is autonomous for much of its lifespan.
\end{abstract}

\section{Introduction}

Although several studies have been carried out on porcine luteal tissue in vitro (Duncan, Bowerman, Anderson, Hearn \& Melampy, 1961; Cook, Kaltenbach, Norton \& Nalbandov, 1967; Cook, Niswender, Sutterlin, Norton \& Nalbandov, 1968; Preumont, Cooke \& Ryan 1969; Birnbaumer, Yang, Hunzicker-Dunn, Bockaert \& Duran, 1976), there remains considerable controversy about stimulation of progesterone production in vitro by gonadotrophins of porcine or other origin. It has been shown that the porcine corpus luteum (CL) in vivo is virtually autonomous, in that if hypophysectomy is carried out after the ovulatory LH surge then the $\mathrm{CL}$ are maintained for the approximate length of one oestrous cycle (see Anderson \& Melampy, 1967). Also, the gland is refractory to the luteolytic effects of anti-ovine LH and prostaglandin F-2 $\alpha$ until at least 10-12 days after ovulation (Spies, Slyter \& Quadri, 1967; Diehl \& Day, 1974). The present study was to examine the progesterone production and responsiveness of luteal tissue recovered during and after this refractory period.

\section{Materials and Methods}

\section{Tissue collection}

Immature gilts (pure-bred White or White crosses) aged 6-9 months and weighing approximately $100 \mathrm{~kg}$ were induced to ovulate by subcutaneous injections of 1000 i.u. PMSG (Organon Laboratories, Morden, Surrey, U.K.) followed by 500 i.u. hCG (Organon) given intramuscularly 4 days later at a similar time $(09: 00 \mathrm{~h})$; ovulation was expected to occur at $40 \mathrm{~h}$

* Present address: Department of Biochemistry, Royal Free Hospital School of Medicine, University of London, 8 Hunter Street, London WC1N 1BP, U.K. 
after the hCG injection, i.e. 01:00 h (Dziuk \& Gehlbach, 1966; Baker \& Coggins, 1968). The animals were sent for slaughter 9 or 15 days after the hCG injection and the ovaries were obtained immediately after slaughter, transported to the laboratory and the CL dissected out. The interval between slaughter and dissection was always less than $1 \mathrm{~h}$. The ovaries were therefore taken $6 \frac{1}{2}$ or $12 \frac{1}{2}$ days after ovulation.

\section{Incubations}

Luteal tissue fragments. The luteal tissue obtained from several pooled CL from each of 4 animals was finely minced with two scalpel blades and washed twice in $50 \mathrm{ml}$ Hank's balanced salt solution without calcium and magnesium (HBSS) (Flow Laboratories, Irvine, U.K.). The tissue was then weighed into aliquots of approximately $20 \mathrm{mg}$, placed into glass scintillation vials and $2 \mathrm{ml}$ Eagle's minimum essential medium (EMEM) (Flow Laboratories) were added. The substances added to the incubations were bovine LH (NIH-LH-B 10), hCG (Sigma, Poole, Dorset, U.K.), dibutyryl cAMP (Sigma) and testosterone (Sigma) to give final concentrations in $1 \mathrm{ml}$ medium of $1 \mu \mathrm{g} \mathrm{bLH}, 10-50$ i.u. hCG, $10 \mathrm{~mm}$-dbcAMP and $100 \mathrm{ng}$ testosterone. After gassing with $95 \% \mathrm{O}_{2} / 5 \% \mathrm{CO}_{2}$ for $10 \mathrm{sec}$ the vessels were sealed and incubated in replicates of 4 or 6 in a shaking water bath for $3 \mathrm{~h}$ at $37^{\circ} \mathrm{C}$. The tissue and medium were then separated by centrifugation at $100 \mathrm{~g}$ for $5 \mathrm{~min}$ and the tissue subsequently homogenized in absolute alcohol. The ethanolic extract and the medium were assayed for progesterone as described below. Progesterone production was calculated by subtracting the progesterone concentration in tissue aliquots before incubation from the total progesterone in the medium and tissue after incubation.

Dissociated cells. Washed and minced luteal tissue obtained from the same 4 animals as above was placed in $0.1 \%$ collagenase/dispase (Boehringer Ltd, Lewes, East Sussex, U.K.) in HBSS at a volume of $10 \mathrm{ml} / \mathrm{g}$ tissue and incubated at $37^{\circ} \mathrm{C}$ for $1 \mathrm{~h}$ while being agitated by a magnetic stirrer. Several different enzyme preparations were tested for cell yield and viability and collagenase/dispase produced the optimum yield, viability and responsiveness to gonadotrophins (Hunter, 1980). The dissociation process was aided by drawing the tissue gently up and down a syringe every $20 \mathrm{~min}$. The cell suspension was then filtered through nylon mesh (100 $\mu \mathrm{m}$ ) and washed twice in $50 \mathrm{ml}$ HBSS. The cells were collected by centrifugation at $100 \mathrm{~g}$ for 10 min and counted twice with a haemocytometer; viability was estimated by the trypan blue exclusion test (Tennant, 1964). After dissociation, the average cell yield was $20 \times 10^{6}$ viable cells $/ \mathrm{g}$ tissue, and viability values were $>80 \%$ viable before incubation and $>75 \%$ viable after incubation. Incubations were set up of 100000 viable cells in $1 \mathrm{ml}$ EMEM in vials, and 4 aliquots were immediately frozen for subsequent estimation of the steroid in the medium before incubation. The incubations were then carried out in quadruplicate or triplicate as described above for the tissue fragments.

Some of the dissociated luteal cells were separated into populations of large and small cells by a modification of the method of Lemon \& Loir (1977), which involved sedimenting the cells on a BSA gradient at unit gravity. The pellets of separated cells obtained were examined under the light microscope and fractions containing the same cell type were pooled. The incubations involved 30 000-50 000 cells of each size in triplicate and were carried out as described above.

\section{Radioimmunoassay}

The progesterone assay was based on the method of Scaramuzzi, Corker, Young \& Baird (1975) using an antiserum raised in a sheep to a progesterone $11 \alpha$-hemisuccinate-bovine serum albumin conjugate. The antiserum was used at a dilution of 1:25000 and showed negligible cross-reactivity with androgens and oestrogens $(<0.1 \%)$, pregnenolone $(0.22 \%)$, $17 \alpha$-hydroxyprogesterone $(<0.01 \%)$ and $20 \alpha$ - and $20 \beta$-dihydroprogesterone $(<1 \%)$. The limit of sensitivity of the assay was $25 \mathrm{pg} /$ tube and the intra- and inter-assay co-efficients of variation were $7.9 \%$ $(n=24)$ and $14.8 \%(n=40)$ respectively. 
Statistical analysis

All data were analysed by Student's $t$ test (unpaired).

\section{Results}

\section{CL tissue fragments and dissociated cells}

The results in Table 1 show that bLH and cAMP significantly enhanced progesterone production by the $12 \frac{1}{2}$ day tissue and cells, but if testosterone was also present then the response to bLH was no longer significant. Progesterone production by the tissue and cells recovered $6 \frac{1}{2}$ days after ovulation was not significantly increased by any of the treatments, but the control level of synthesis was greater than that of the tissue and cells recovered later in the luteal phase.

Table 1. Progesterone production by minced tissue and dissociated cells of CL recovered at $6 \frac{1}{2}$ and $12 \frac{1}{2}$ days after ovulation induced in gilts

\begin{tabular}{|c|c|c|c|c|c|c|c|c|c|c|}
\hline \multirow[b]{2}{*}{$\begin{array}{l}\text { Age of } \\
\text { tissue } \\
\text { (days) }\end{array}$} & \multicolumn{5}{|c|}{ Minced tissue ( $\mu \mathrm{g}$ progesterone $/ \mathrm{g}$ tissue $/ 3 \mathrm{~h}$ ) } & \multicolumn{5}{|c|}{ Isolated cells (pg progesterone $/ 1000$ cells $/ 3 \mathrm{~h}$ ) } \\
\hline & Control & $\begin{array}{c}\text { bLH } \\
(1 \mu \mathrm{g} / \mathrm{ml})\end{array}$ & $\begin{array}{l}\text { dcAMP } \\
(10 \mathrm{mM})\end{array}$ & $\begin{array}{l}\text { Testosterone } \\
(100 \mathrm{ng} / \mathrm{ml})\end{array}$ & $\begin{array}{r}\text { bL,H }(1 \mu \mathrm{g} / \mathrm{ml}) \\
+ \text { testosterone } \\
(100 \mathrm{ng} / \mathrm{ml})\end{array}$ & Control & $\begin{array}{c}\mathrm{bLH} \\
(1 \mu \mathrm{g} / \mathrm{ml})\end{array}$ & $\begin{array}{c}\text { dcAMP } \\
(10 \mathrm{mM})\end{array}$ & $\begin{array}{l}\text { Testosterone } \\
(100 \mathrm{ng} / \mathrm{ml})\end{array}$ & $\begin{array}{c}\mathrm{bLH}(1 \mu \mathrm{g} / \mathrm{ml}) \\
+ \text { testosterone } \\
(100 \mathrm{ng} / \mathrm{ml})\end{array}$ \\
\hline $6 \frac{1}{2}$ & $\begin{array}{r}59.8 \\
+6.9\end{array}$ & $\begin{array}{r}68.6 \\
\pm 5.4\end{array}$ & $\begin{array}{r}58.5 \\
\pm 1.8\end{array}$ & $\begin{array}{r}67.3 \\
+3.7\end{array}$ & NI & $\begin{array}{r}130.0 \\
\pm 26.3\end{array}$ & $\begin{array}{r}150.0 \\
\pm 12.5\end{array}$ & $\begin{array}{l}125.0 \\
\pm 5.0\end{array}$ & $\begin{array}{r}111.3 \\
\pm 10.0\end{array}$ & $\begin{array}{r}86 \cdot 3 \\
\pm 8 \cdot 8\end{array}$ \\
\hline $6 \frac{1}{2}$ & $\begin{array}{r}55.8 \\
\pm 7.0\end{array}$ & $\begin{array}{r}54.9 \\
+7.9\end{array}$ & $\begin{array}{r}60.8 \\
\pm 5.2\end{array}$ & $\begin{array}{r}57.6 \\
\pm 12.3\end{array}$ & NI & $\begin{array}{r}75.0 \\
+5.0\end{array}$ & $\begin{array}{r}77.5 \\
\pm 6.3\end{array}$ & $\begin{array}{r}81 \cdot 3 \\
\pm 6.3\end{array}$ & $\begin{array}{r}72.5 \\
\pm 7.5\end{array}$ & $\begin{array}{r}70.0 \\
\pm 6.3\end{array}$ \\
\hline $12 \frac{1}{2}$ & $\begin{array}{r}4.1 \\
\pm 1.2\end{array}$ & $\begin{array}{c}11.7 \\
\pm 2.7^{*}\end{array}$ & $\begin{array}{c}26 \cdot 6 \\
\pm 3 \cdot 2^{* *}\end{array}$ & $\begin{array}{r}2.7 \\
\pm 0.9\end{array}$ & $\begin{array}{r}4.9 \\
+3.5\end{array}$ & $\begin{array}{r}19.0 \\
\pm 6.3\end{array}$ & $\begin{array}{c}50.5 \\
\pm 3.8^{* *}\end{array}$ & $\begin{array}{c}66.0 \\
\pm 16.3^{*}\end{array}$ & $\begin{array}{r}31.3 \\
\pm 5.0\end{array}$ & $\begin{array}{r}31.3 \\
\pm 2.5\end{array}$ \\
\hline $12 \frac{1}{2}$ & $\begin{array}{r}4.2 \\
\pm 1.0\end{array}$ & $\begin{array}{c}9.0 \\
\pm 1.0^{* *}\end{array}$ & $\begin{array}{c}17.8 \\
\pm 1.7^{* *}\end{array}$ & $\begin{array}{r}4.9 \\
+1.6\end{array}$ & $\begin{array}{r}5.7 \\
\pm 1.3\end{array}$ & $\begin{array}{r}53.8 \\
\pm 3.8\end{array}$ & $\begin{array}{c}77.5 \\
\pm 5.0^{* *}\end{array}$ & $\begin{array}{c}78.8 \\
\pm 5.0^{* *}\end{array}$ & $\begin{array}{r}48.8 \\
\pm 1.2\end{array}$ & $\begin{array}{r}53.8 \\
\pm 3.8\end{array}$ \\
\hline
\end{tabular}

Values are mean \pm s.e.m. for 6 (minced tissue) or 4 (isolated cells) samples from several pooled CL from 1 animal. Each row represents 1 animal. $\mathrm{NI}=$ not incubated.

Values significantly different from the control value: $* P<0.05, * * P<0.005$.

\section{Response to $h C G$}

Tissue and cells from $6 \frac{1}{2}$-day CL were unaffected even by high concentrations of hCG, but the tissue and cells from $12 \frac{1}{2}$ day CL showed enhanced progesterone production with increasing hCG dose although the control production was lower (Text-fig. 1).

\section{Steroid production by large and small luteal cells}

After separation, a virtually pure preparation of small cells (10-20 $\mu \mathrm{m}$ diameter) was obtained ( $>95 \%)$. The large cell preparation (30-45 $\mu \mathrm{m}$ diam., $>60 \%$ purity) did contain some contaminating small cells but the proportion of large cells was considerably enhanced above that in the original mixed cell suspension (15-20\% large cells). Some very small cells $<10 \mu \mathrm{m}$ in diameter were discarded with the red blood cells after separation.

Small and large cells from $6 \frac{1}{2}$-day $\mathrm{CL}$ did not show increased progesterone production in response to $\mathrm{LH}$, although progesterone production by the large cells was considerable. However, both cell types from the $12 \frac{1}{2}$-day tissue responded significantly. 

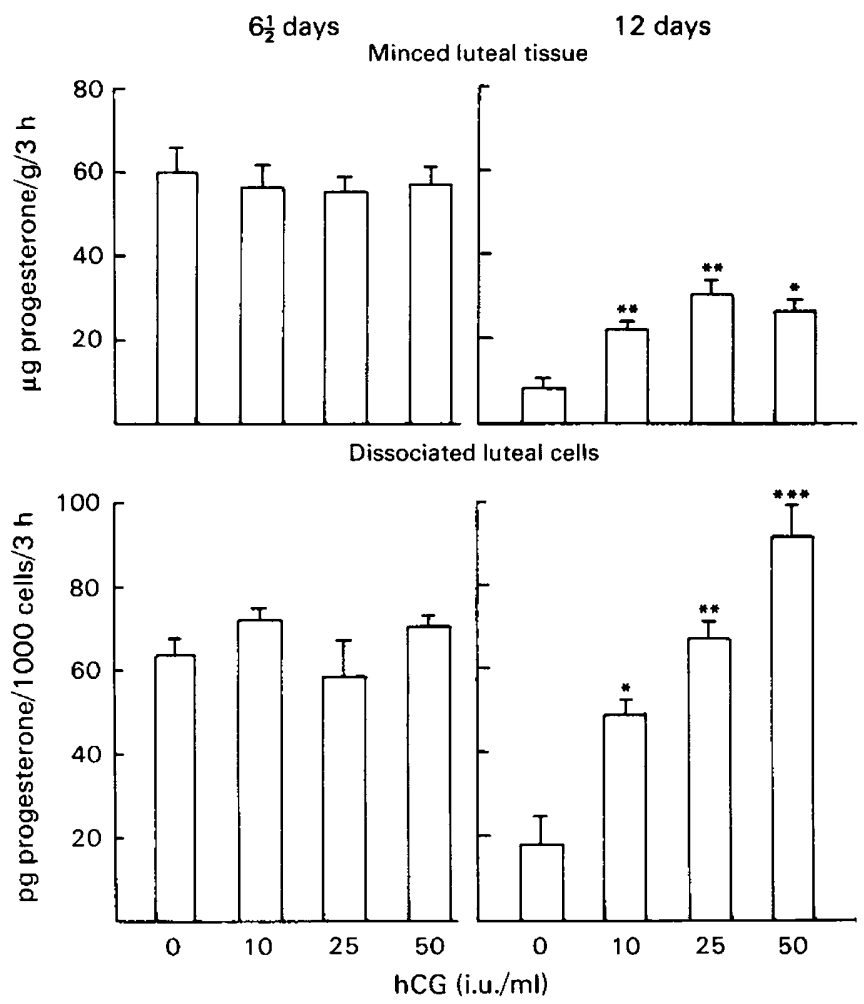

Text-fig. 1. Progesterone production in response to increasing concentrations of hCG by luteal tissue and dissociated cells recovered at $6 \frac{1}{2}$ and $12 \frac{1}{2}$ days after ovulation. Each value is the mean \pm s.e.m., $n=4$ for minced tissue and $n=3$ for isolated cells. Progesterone production was calculated as described in the 'Methods'. Values significantly different from the control value: * $P<0.05,{ }^{* *} P<0.01,{ }^{* * *} P<0.005$.

\section{Discussion}

The above results indicate that the porcine corpus luteum is autonomous for much of its lifespan. When CL are recovered $6 \frac{1}{2}$ days after ovulation, and the minced tissue studied in vitro, progesterone production is high and cannot be further stimulated by gonadotrophins or cAMP (Table 1). The fact that dbcAMP, which bypasses the gonadotrophin-receptor interaction step cannot enhance steroidogenesis suggests that the tissue is already synthesizing at maximum capacity, and this is supported by the production rates detected in vivo (Masuda, Anderson, Henricks \& Melampy, 1967). The incubations of the dissociated cells (Table 1) confirm the results from the minced luteal tissue in that the cells also appear to be producing progesterone at maximum rate.

By contrast, for tissue recovered $12 \frac{1}{2}$ days after ovulation, control levels of synthesis were lower than for tissue recovered earlier in the luteal phase. However, progesterone production by the minced tissue and dissociated cells was significantly stimulated by gonadotrophins and dibutyryl cAMP to levels similar to those produced by the $6 \frac{1}{2}$-day CL. By 12 days after ovulation, the progesterone levels in vivo are beginning to fall from maximal (Masuda et al., 1967) and this is reflected by the production in vitro. The treatment doses used were based on data from previous in-vitro studies of luteal tissue (Savard, Marsh \& Rice, 1965; Cook et al., 1967). Tests with the two populations of luteal cells (Table 2) showed that it is the large luteal 
cells which are the more active in terms of progesterone production, but both cell types removed $12 \frac{1}{2}$ days after ovulation were responsive to stimulation.

Table 2. Progesterone production by separated cells from pig corpora lutea recovered $6 \frac{1}{2}$ and $12 \frac{1}{2}$ days after ovulation

\begin{tabular}{|c|c|c|c|c|}
\hline \multirow{2}{*}{$\begin{array}{l}\text { Age } \\
\text { tissue } \\
\text { (days) }\end{array}$} & \multirow{2}{*}{$\begin{array}{c}\text { Cell } \\
\text { population }\end{array}$} & \multirow{2}{*}{$\begin{array}{l}\text { \% Large } \\
\text { cells }\end{array}$} & \multicolumn{2}{|c|}{$\begin{array}{l}\text { Progesterone produced } \\
(\mathrm{pg} / 1000 \text { cells } / 3 \mathrm{~h})\end{array}$} \\
\hline & & & Control & $\mathrm{bLH}(1 \mu \mathrm{g} / \mathrm{ml})$ \\
\hline $6 \frac{1}{2}$ & Small & $<5$ & $\begin{array}{r}12.5 \\
\pm 0.1\end{array}$ & $\begin{array}{r}11.4 \\
\pm 1.1\end{array}$ \\
\hline $6 \frac{1}{2}$ & Large & 62 & $\begin{array}{r}446 \cdot 3 \\
\pm 30 \cdot 3\end{array}$ & $\begin{array}{r}308 \cdot 8 \\
\pm 65 \cdot 0\end{array}$ \\
\hline $12 \frac{1}{2}$ & Small & $<5$ & $\begin{array}{r}7.0 \\
+6.6\end{array}$ & $\begin{array}{l}24 \cdot 1 \\
\pm 2 \cdot 0^{* *}\end{array}$ \\
\hline $12 \frac{1}{2}$ & Large & 73 & $\begin{array}{r}262.3 \\
\pm 32.4\end{array}$ & $\begin{array}{c}402 \cdot 2 \\
\pm 41 \cdot 3^{*}\end{array}$ \\
\hline
\end{tabular}

Values are mean \pm s.e.m. for 3 incubations of cells recovered from several CL from 1 animal.

Values significantly different from control: ${ }^{*} P<0.05,{ }^{* *} P<0.01$.

Although the small cells were individually less active in terms of progesterone production, they are still likely to play an important role in vivo because they are present as a large percentage of the total luteal cells.

The major role played by androgens and oestrogens in controlling the response of the ovary to gonadotrophins has been well documented (Nimrod \& Lindner, 1976; Haney \& Schomberg, 1978; Thanki \& Channing, 1978; Williams, Roth, Marsh \& LeMaire, 1979), and in the above experiments testosterone was found to inhibit the response to bLH. The porcine CL can aromatize testosterone to oestradiol (Hunter, 1980) and so testosterone may be exerting its inhibitory effect after being aromatized to oestradiol, as oestradiol has been demonstrated to inhibit the hydroxysteroid dehydrogenase isomerase system of human and ovine CL (Depp, Cox, Pion, Conrad \& Henricks, 1973; Caffrey, Nett, Abel \& Niswender, 1979).

The expenses incurred in this study were defrayed out of a grant to Professor T. G. Baker by the Ford Foundation (No. 760-0532). I am grateful to Dr R. H. F. Hunter for providing the porcine tissue.

\section{References}

Anderson, L.L. \& Melampy, R.M. (1967) Hypophysial and uterine influences on pig luteal function. In Reproduction in the Female Mammal, pp. 285-316. Eds G. E. Lamming \& E. C. Amoroso. Butterworths, London.

Baker, R.D. \& Coggins, E.G. (1968) Control of ovulation rate and fertilization in prepubertal gilts. $J$. Anim. Sci. 27, 1607-1610.

Birnbaumer, L., Yang, P., Hunzicker-Dunn, M., Bockaert, J. \& Duran, J.M. (1976) Adenyl cyclase activities in ovarian tissues. I. Homogenization and conditions of assay in Graafian follicles and corpora lutea of rabbits, and pigs: regulation by ATP, and some comparative properties. Endocrinology 99, 163-184.
Caffrey, J.L., Nett, T.M., Abel, J.H., Jr \& Niswender, G.D. (1979) Activity of $3 \beta$-hydroxy- $\Delta^{5}$-steroid dehydrogenase $/ \Delta^{5}-\Delta^{4}$-jsomerase in the ovine corpus luteum. Biol. Reprod. 20, 279-287.

Cook, B., Kaltenbach, C.C., Norton, H.W. \& Nalbandov, A.V. (1967) Synthesis of progesterone in vitro by porcine corpora lutea. Endocrinology 81, 573584.

Cook, B., Niswender, G.D., Sutterlin, N.S., Norton, H.W. \& Nalbandov, A.V. (1968) The effect of some steroids, including estrogens, on progesterone synthesis by porcine corpora lutea in vitro. Steroids 11 , 321-336.

Depp, R., Cox, D.W., Pion, R.J., Conrad, S.H. \& Henricks, W.L. (1973) Inhibition of the pregneno- 
lone $\Delta^{5}-3 \beta$-hydroxysteroid dehydrogenase- $\Delta^{5-4}$-iso merase system of human placenta and corpus luteum of pregnancy. Gynaecol. Invest. 4, 106-111.

Diehl, J.R. \& Day, B.N. (1974) Effect of prostaglandin $\mathrm{F}_{2 \alpha}$ on luteal function in swine. J. Anim. Sci. 39, 392-396.

Duncan, G.W., Bowerman, A.M., Anderson, L.L., Hearn, W.R. \& Melampy, R.M. (1961) Factors influencing in vitro synthesis of progesterone. Endocrinology 68, 199-207.

Dziuk, P.J. Gehlbach, G.D. (1966) Induction of ovulation and fertilization in the immature gilt. $J$. Anim. Sci. 26, $410-413$.

Haney, A.F. \& Schomberg, D.W. (1978) Steroidal modulation of progesterone secretion by granulosa cells from large porcine follicles: a role for androgens and oestrogens in controlling steroidogenesis. Biol. Reprod. 19, 242-248.

Hunter, M.G. (1980) Studies on the corpus luteum in vitro. Ph.D. thesis, University of Edinburgh.

Lemon, M. \& Loir, M. (1977) Steroid release in vitro by two luteal cell types in the corpus luteum of the pregnant sow. J. Endocr. 72, 351-359.

Masuda, H., Anderson, L.L., Henricks, D.M. \& Melampy, R.M. (1967) Progesterone in ovarian venous plasma and corpora lutea of the pig. Endocrinology 80, 240-246.

Nimrod, A. \& Lindner, H.R. (1976) A synergistic effect of androgen on the stimulation of progesterone secretion by FSH in cultured rat granulosa cells. Mol. cell. Endocr. 5, 315-320.

Preumont, P., Cooke, I.J. \& Ryan, K. (1969) Oestrogen biosynthesis and steroid metabolism in the porcine ovary. Acta endocr., Copenh. 62, 449-460.

Savard, K., Marsh, J. \& Rice, B.F. (1965) Gonadotrophins and ovarian steroidogenesis. Recent Prog. Horm. Res. 21, 285-365.

Scaramuzzi, RJ., Corker, C.S., Young, G. \& Baird, D.T. (1975) Production of antisera to steroid hormones in sheep. In Steroid Immunoassay, pp. 111-122. Eds E. D. H. Cameron, S. G. Hillier \& K. Griffiths. Alpha Omega Alpha, Cardiff.

Spies, H.G., Slyter, A.L. \& Quadri, S.K. (1967) Regression of corpora lutea in pregnant gilts administered antiovine LH rabbit serum. J. Anim. Sci. 26, 768-771.

Tennant, J.R. (1964) Evaluation of the trypan blue techniques for determination of cell viability. Transplantation 2, 685-691.

Thanki, K.H. \& Channing, C.P. (1978) Effects of follicle stimulating hormone and oestradiol upon progesterone secretion by porcine granulosa cells in tissue culture. Endocrinology 103, 74-80.

Williams, M.T., Roth, M.S., Marsh, J.M. \& LeMaire, W.J. (1979) Inhibition of human chorionic induced progesterone synthesis by oestradiol in isolated human luteal cells. J. clin. Endocr. Metab. 48, $437-440$.

Received 2 February 1981 